\title{
Urgensi Pembentukan Undang-Undang Komisi Kebenaran dan Rekonsiliasi di Indonesia dalam Upaya Penuntasan Pelanggaran HAM Berat di Masa Lalu
}

\author{
Ali Abdurahman* dan Mei Susanto**
}

\begin{abstract}
Abstrak
Sampai saat ini, upaya penuntasan pelanggaran HAM berat di masa lalu masih menjadi hutang yang belum tertunaikan. Upaya rekonsiliasi yang hendak ditempuh pemerintah, sebagai salah satu alternatif penyelesaian seharusnya tidak boleh meninggalkan upaya mengungkap kebenaran. Pembentukan Undang-Undang Komisi Kebenaran dan Rekonsiliasi (UU KKR) yang sejalan dengan UUD 1945 dan instrumen HAM yang berlaku secara universal sebagaimana diamanatkan Putusan MK Nomor 6/PUU-IV/2006 menjadi kebutuhan yang penting dan mendasar. Tanpa adanya UU KKR tersebut, maka upaya rekonsiliasi yang dilakukan pemerintah akan mengalami problem hukum yang pada gilirannya akan semakin menunda penuntasan pelanggaran HAM berat di masa lalu. Bahkan implikasi ketiadaan UU KKR, membuat KKR Aceh yang dibentuk melalui Qanun Aceh Nomor 17 Tahun 2013 seolah mati suri karena dalam menjalankan tugas dan kewenangannya akan berbenturan dengan peraturan perundang-undangan yang lebih tinggi yang tidak mampu dijangkau oleh Qanun Aceh tersebut. Karenanya, Pemerintah dan DPR seharusnya meningkatkan komitmen dan political will-nya untuk segera melakukan pembahasan RUU KKR, dan segera menghilangkan kebiasaan yang hanya memasukkan RUU KKR dalam daftar program legislasi nasional.
\end{abstract}

Kata Kunci: komisi kebenaran rekonsiliasi, pelanggaran HAM berat, pembentukan undangundang, prolegnas, Qanun Aceh.

\section{Urgency of Establishing Law Commission on the Truth and Reconciliation in Indonesia in Effort of Completion Human Rights Violations in the Past}

\begin{abstract}
Up to now, the efforts to resolve human rights violations are still considered as a debt that have not been fullfilled. The reconciliation steps that have been taken by the government, as one of the alternative dispute settlement should not put aside its aim to uncover the truth. The Establishment of Law on Truth and Reconciliation Commission (the Law) which is in line with the 1945 Constitution and international human rights instruments that apply universally as mandated by the Constitutional Court Decision Number 6/PUU-IV/2006 became fundamental needs. In the absence of the Law, the government's reconciliation efforts will run into legal problems, which in turn will further delay the completion of serious human rights violations in the past. In fact, the implications of the absence of the Law, lead to

PADJADJARAN Jurnal IImu Hukum Volume 3 Nomor 3 Tahun 2016 [ISSN 2460-1543] [e-ISSN 2442-9325]

Dosen Fakultas Hukum Universitas Padjadjaran, Jalan Dipati Ukur No. 35 Bandung, abdurahman_ali58@yahoo.com, S.H., M.Hum., Dr. (Universitas Padjadjaran).

** Dosen Fakultas Hukum Universitas Padjadjaran, Jl. Dipati Ukur No. 35 Bandung, Peneliti PSKN FH Unpad, Pengurus Asosiasi Sarjana Hukum Tata Negara (ASHTN) Indonesia, m.susanto@unpad.ac.id, S.H. (Universitas Padjadjaran), M.H. (Universitas Indonesia).
\end{abstract}


the Truth and Reconciliation Commission in Aceh formed by Aceh Qonun Number 17 in 2013 suspended because it collides with the higher legislation that cannot be reached by Aceh Qonun. Therefore, the government and House of Representatives should pay more commitment and its political will for immediate discussion of the Law Truth and Reconciliation Commission, and immediately eliminate the habit that only put the Law on Truth and Reconciliation Commission in the list of national legislation program.

Keywords: truth and reconciliation commission, human rights violations, legislation, national legislation program, Qanun Aceh.

\section{A. Pendahuluan}

Upaya penuntasan pelanggaran Hak Asasi Manusia (HAM) berat masa lalu di Indonesia melalui instrumen Komisi Kebenaran dan Rekonsiliasi (KKR) mengalami hambatan dan tantangan yang tidak mudah. Hal tersebut dapat dilihat dari ketidakseriusan Pemerintah dan DPR dalam menyelesaikan dasar hukum pembentukan KKR, mengingat Undang-Undang Nomor 27 Tahun 2004 tentang Komisi Kebenaran dan Rekonsiliasi (UU KKR) telah dibatalkan secara keseluruhan oleh Mahkamah Konstitusi berdasarkan Putusan Nomor 6/PUU-IV/2006. Itu artinya sudah 10 tahun UU KKR dibatalkan MK, namun tidak ada perkembangan yang berarti dalam upaya penyelesaiannya. RUU KKR hanya dimasukkan dalam daftar program legislasi nasional (prolegenas) 2007-2010, 2010-2014, dan 2015-2019 tanpa ada pembahasan sama sekali (setidaknya sampai dengan tahun 2016).

Padahal pelanggaran HAM berat di masa lalu bukanlah tuduhan tanpa dasar yang dapat dikesampingkan begitu saja. Sejak dikeluarkannya Undang-Undang Nomor 26 Tahun 2000 tentang Pengadilan HAM (UU Pengadilan HAM), Komnas HAM telah menyelidiki 11 peristiwa dugaan pelanggaran HAM berat: ${ }^{1}$

a) Kasus Timor Timur 1999. Laporan hasil penyelidikan telah diserahkan kepada Kejaksaan Agung pada 31 Januari 2000. Kasus ini telah disidik oleh Kejaksaan Agung dan diperiksa pengadilan dan telah sampai tingkat kasasi. Satu terdakwa dinyatakan bersalah;

b) Kasus Tanjung Priok 1984. Laporan hasil penyelidikan telah disampaikan kepada Kejaksaan Agung pada 7 Juli 2000. Telah dilakukan penyidikan dan diperiksa pengadilan dan telah sampai tingkat kasasi. Semua terdakwa dinyatakan bebas;

c) Kasus Peristiwa Irian/Papua 2000 (Abepura 200). Laporan dikirimkan ke

Lihat Firdiansyah, Peran dan Harapan Korban untuk Penyelesaian Pelanggaran Berat HAM Masa Lalu, Jurnal HAM Komnas HAM, 2016, hlm. 4-5, menyebutkan Komnas HAM telah menyelesaikan penyelidikan 10 peristiwa dugaan pelanggaran HAM berat. Khusus untuk dugaan pelanggaran HAM berat di Aceh, penulis dasarkan kepada hasil Ringkasan Eksekutif Laporan Penyelidikan Pelanggaran HAM yang Berat Peristiwa Simpang KKA Aceh oleh Komnas HAM tertanggal 14 Juni 2016, yang dapat dilihat di https://www.komnasham.go.id/index.php/hamberat/2016/09/29/2/ringkasan-eksekutif-laporanpenyelidikan-pelanggaran-ham-yang-berat-peristiwa-simpang-kka-aceh.html, diakses 5 November 2016. 
Kejaksaan Agung pada 17 Mei 2001. Kasus telah disidik dan ditetapkan 2 terdakwa yaitu Drs. Daud Sihombing, dan Brigjen. Johny Wainal Usman. Dua terdakwa telah diperiksa oleh Pengadilan Hak Asasi Manusia. Keduanya dibebaskan;

d) Kasus Trisaksi, Semanggi I dan Semanggi II. Laporan penyelidikan telah disampaikan ke Kejaksaan Agung pada 29 April 2002. Kejaksaan Agung belum melakukan penyidikan dan penuntutan

e) Kasus Mei 1998. Laporan penyelidikan telah disampaikan ke Kejaksaan Agung pada 19 September 2003. Kejaksaan Agung belum melakukan penyidikan dan penuntutan;

f) Kasus Wasior (Juni 2001-Oktober 2002)-Wamena (2003). Laporan penyelidikan telah disampaikan ke Kejaksaan Agung pada 3 September 2004. Kejaksaan Agung belum melakukan penyidikan dan penuntutan;

g) Kasus Penghilangan Orang Secara Paksa 1997-1998. Laporan penyelidikan telah disampaikan ke Kejaksaan Agung pada 3 September 2006. Kejaksaan Agung belum melakukan penyidikan dan penuntutan;

h) Kasus Talangsari 1989. Laporan penyelidikan telah disampaikan ke Kejaksaan Agung pada 16 September 2008. Kejaksaan Agung belum melakukan penyidikan dan penuntutan;

I) Kasus Penembakan Misterius 1982-1985. Laporan penyelidikan telah disampaikan ke Kejaksaan Agung pada 20 Juli September 2012. Kejaksaan Agung belum melakukan penyidikan dan penuntutan;

j) Kasus Tragedi 1965-1966. Laporan penyelidikan telah disampaikan ke Kejaksaan Agung pada 20 Juli 2012. Kejaksaan Agung belum melakukan penyidikan dan penuntutan;

k) Kasus Simpang KKA di Aceh 1999. Laporan penyelidikan diselesaikan pada tanggal 14 Juni 2016 yang kemudian diteruskan kepada Kejaksaan Agung.

Dari 11 dugaan pelanggaran HAM berat tersebut, 3 telah dibawa ke Pengadilan HAM, sementara itu 8 diantaranya belum ada tindak lanjut oleh Kejaksaan Agung baik pada era pemerintahan Susilo Bambang Yudhoyono (2004-2014), maupun pemerintahan Joko Widodo (2014-2019) yang saat ini menjabat.

Khusus untuk Pemerintahan Joko Widodo, sesuai dengan Nawacita ${ }^{2}$ yang dijanjikannya, tepatnya Nawacita nomor empat yang menyatakan "Kami akan menolak negara lemah dengan melakukan reformasi sistem dan penegakan hukum yang bebas korupsi, bermartabat dan terpercaya. Kami akan memprioritaskan ...; perlindungan anak, perempuan dan kelompok masyarakat termarjinal, serta

Nawacita merupakan 9 (sembilan) agenda prioritas Presiden Joko Widodo dan Wakil Presiden Jusuf Kalla yang dikeluarkan saat berkampanye pada pemilihan Presiden 2014. Lebih lengkap lihat Jokowi dan Jusuf Kalla, "Jalan Perubahan Untuk Indonesia Yang Berdaulat, Mandiri dan Berkepribadian, Visi, Misi, dan Program Aksi", 2014. Diakses melalui kpu.go.id/koleksigambar/VISI_MISI_Jokowi-JK.pdf 
penghormatan HAM dan penyelesaian secara berkeadilan terhadap kasus-kasus pelanggaran HAM pada masa lalu" (cetak tebal penulis), telah mendorong pembentukan tim gabungan untuk menyelesaikan kasus pelanggaran HAM berat masa lalu yang terdiri dari Komnas HAM, Kementerian Koordinator Politik Hukum dan Keamanan, Kejaksaan Agung, Kementerian Hukum dan HAM, Polri, dan TNI pada Mei 2015. ${ }^{3}$ Adapun target tim gabungan tersebut adalah penyelesaian kasus pembantaian massal 1965, penembakan misterius, kasus Talangsari (Lampung), kerusuhan Mei 1998, dan penculikan sejumlah aktivis, yang hendak diselesaikan dengan jalur rekonsiliasi. ${ }^{4}$ Jalur rekonsiliasi ini memunculkan opsi antara meminta maaf atau penyesalan yang akan dilakukan oleh Pemerintahan Joko Widodo terhadap pelanggaran HAM berat masa lalu tersebut.

Disinilah menariknya persoalan penyelesaian pelanggaran HAM di masa lalu yang hendak dilakukan Pemerintahan Joko Widodo. Upaya yang hendak dilakukan dalam bentuk rekonsiliasi yang pada ujungnya berupa permintaan maaf atau penyesalan masih menimbulkan kerancuan dan problema hukum. Kerancuannya adalah bentuk rekonsiliasi pada umumnya dibarengi dengan pengungkapan kebenaran terutama dari pihak korban bukan langsung dalam bentuk permohonan maaf atau penyesalan yang dilakukan oleh pemerintah. Sementara itu problema hukumnya adalah belum ada payung hukum berupa UU Komisi Kebenaran dan Rekonsiliasi sebagaimana telah disinggung. Karena itu, apabila tim gabungan yang dibentuk Pemerintahan Joko Widodo tersebut telah selesai melakukan tugasnya, dan Pemerintahan Joko Widodo benar-benar melakukan permintaan maaf atau penyesalan, maka masa depan Komisi Kebenaran dan Rekonsiliasi sebagai salah satu amanah peraturan perundang-undangan semakin tidak jelas.

Selain itu, persoalan juga muncul dengan telah dibentuknya KKR Aceh berdasarkan Qanun Pemerintah Aceh Nomor 17 Tahun 2013 tentang Komisi Kebenaran dan Rekonsiliasi Aceh (Qanun KKR Aceh) sebagai inisiatif Pemerintahan Daerah Provinsi Aceh untuk menjalankan amanat Undang-Undang Nomor 11 Tahun 2006 tentang Pemerintahan Aceh (UU Pemerintahan Aceh) yang memberikan mandat pembentukan KKR di Aceh. Qanun KKR Aceh sendiri dikritik oleh Pemerintah Pusat melalui Kementerian Dalam Negeri, yang menyebut seharusnya menunggu UU KKR nasional. ${ }^{5}$

Berdasarkan persoalan-persoalan tersebut, maka permasalahan yang akan dibahas dalam tulisan ini adalah sebagai berikut: pertama, bagaimana urgensi

Liputan 6, "Usut Kasus HAM Berat, Pemerintah Bentuk Tim Gabungan”, http://news.liputan6.com/read/2237035/usut-kasus-ham-berat-pemerintah-bentuk-tim-gabungan, diakses 5 November 2016.

CNN Indonesia, "Jaksa Agung Ada Titik Terang Dalam Kasus HAM Masa Lalu", http://www.cnnindonesia.com/nasional/20150702144002-12-63889/jaksa-agung-ada-titik-terang-dalam-kasus-ham-masa-lalu/, diakses 5 November 2016.

BBC Indonesia, "Kemendagri Pertanyakan KKR Aceh", http://www.bbc.com/indonesia/berita_indonesia/2013/12-/131227_kemendagri_pertanyakan_kkraceh, diakses 6 November 2016. 
pembentukan UU KKR dalam upaya penuntasan pelanggaran HAM berat di masa lalu; kedua, bagaimana implikasi ketiadaan UU KKR terhadap KKR Aceh.

\section{B. Konsep Umum Komisi Kebenaran dan Rekonsiliasi}

Berbagai penelitian menunjukkan bahwa KKR merupakan fenomena yang timbul di era transisi politik dari suatu rezim otoriter ke rezim demokratis, terkait dengan persoalan penyelesaian kejahatan kemanusiaan yang dilakukan rezim sebelumnya. ${ }^{6}$ Sudah menjadi rahasia umum, jika rezim otoriter kerap mempergunakan kekerasan bahkan pembunuhan dalam melanggengkan rezimnya, yang membuat banyak terjadi pelanggaran HAM berat. Karena itu, runtuhnya rezim otoriter yang kemudian berubah kepada rezim yang lebih demokratis, mendorong pemerintahan transisi untuk mencari solusi atas pelanggaran HAM berat yang dilakukan rezim otoriter tersebut. Pada saat itu, sebagaimana disebutkan Satya Arinanto, muncul pertanyaan: "haruskah masyarakat menghukum masa lalunya, ataukah membiarkan kaitan dengan masa lalu (bygones) tetap eksis?"7 Pertanyaan tersebut muncul sebagai upaya mencari keadilan transisional, yang dalam praktiknya dilakukan oleh beberapa negara dengan metode yang berbeda-beda, serta berbeda-beda pula hasilnya. Misalnya bangsa Rusia yang membawa komunisme ke pengadilan, Afrika Selatan melalui pembentukan Komisi Kebenaran dan Rekonsiliasi, Uruguay dengan cara melakukan referendum untuk tidak menyelidiki pemerintahan militer yang penuh kekerasan. ${ }^{8}$

Bagi Rhona K.M. Smith, dkk, kesadaran pentingnya menuntaskan pelanggaran berat di masa lalu diyakini merupakan jalan menuju demokrasi. ${ }^{9}$ Tidak mungkin sebuah bangsa dapat hidup bersatu padu dalam damai di atas sejarah penuh luka dan kekerasan. Proses transisi menuju demokrasi harus berjalan di atas proses sejarah yang jujur, adil, dan bertanggung jawab. Pemerintahan yang baru harus menemukan jalan keluar untuk meneruskan detak nadi kehidupan, menciptakan ulang ruang nasional yang damai dan layak dihuni, membangun semangat dan upaya rekonsiliasi dengan para musuh masa lampau, dan mengurung kekejaman masa lampau dalam sangkar masa lampaunya sendiri.

Upaya tersebut dilakukan dengan mencoba mendamaikan antara kecenderungan menghukum di satu sisi dengan kecenderungan memberi maaf atau amnesti di sisi lain. ${ }^{10}$ Mengingat pelanggaran HAM berat yang dilakukan rezim otoriter sebelumnya mengandung dimensi politik, psikologis, sosial dan hukum yang kompleks, maka upaya mendamaikan sebagai 'jalan tengah' tersebut acap kali tidak memuaskan banyak pihak, terutama korban, keluarga korban, dan organisasi

\footnotetext{
Rhona K.M. Smith, dkk, Hukum Hak Asasi Manusia, Yogyakarta: Pusham UII, 2010, hlm. 364.

Satya Arinanto, Hak Asasi Manusia dalam Transisi Politik Di Indonesia, Jakarta: PSHTN FH UI, 2008, hlm. 151.

Ibid., hlm. 153-155.

Rhona K.M. Smith, dkk, Op.cit., hlm. 365

Ibid., hlm. 364.
} 
masyarakat sipil, akan tetapi itulah usaha pemerintahan transisi yang dapat dilakukan. ${ }^{11}$ Walau demikian upaya melakukan pengungkapan kebenaran dan rekonsiliasi adalah salah satu upaya yang dapat ditempuh demi tuntasnya pelanggaran HAM berat di masa lalu agar tidak menjadi 'hantu' yang terus membayangi. Apalagi terkadang upaya hukum melalui pengadilan sering kali tidak dapat terlaksana karena beragam persoalan ataupun terlaksana namun mengecewakan.

Berkaitan dengan KKR sendiri, tidak ditemukan definisi yang dapat diterima secara umum. ${ }^{12}$ KKR merupakan penamaan umum terhadap komisi-komisi yang dibentuk pada situasi transisi politik dalam rangka menangani pelanggaran HAM berat atau kejahatan hak asasi manusia di masa lalu. Menurut berbagai penelitian, tidak kurang 20 KKR telah ada di berbagai negara yang mempunyai nama, mandat, dan wewenang yang berbeda satu sama lainnya. ${ }^{13}$

Meski demikian, Priscilla Hayner mengemukakan 6 elemen yang dapat dikatakan sebagai karakter umum KKR, yaitu: (1) fokus penyelidikannya pada kejahatan masa lalu; (2) terbentuk beberapa saat setelah rezim otoriter tumbang; (3) tujuannya adalah mendapatkan gambaran yang komprehensif mengenai kejahatan hak asasi manusia dan pelanggaran hukum internasional pada suatu kurun waktu tertentu, dan tidak memfokuskan pada suatu kasus; (4) keberadaannya adalah untuk jangka waktu tertentu, biasanya berakhir setelah laporan akhirnya selesai dikerjakan; (5) ia memiliki kewenangan untuk mengakses informasi ke lembaga apa pun, dan mengajukan perlindungan untuk mereka yang memberikan kesaksian; dan (6) pada umumnya dibentuk secara resmi oleh negara baik melalui keputusan presiden atau melalui undang-undang, atau bahkan oleh PBB seperti KKR di ELSalvador. ${ }^{14}$

Komisi 'kebenaran' dalam konteks ini adalah sebuah komisi yang harus mencari, menemukan dan mengemukakan fakta atau kenyataan tentang suatu peristiwa dengan segala akibatnya. Menimbang dan menempatkan keadilan korban dan pelaku sebagai prinsip kerja, tidak boleh berlaku tidak fair dan tidak adil terhadap pelaku sekalipun, dan yang terakhir semua temuan harus dinyatakan secara benar, fair, jujur dan transparan, serta tidak manipulatif. ${ }^{15}$ Hal tersebut tidak lain agar Komisi Kebenaran dapat dipercaya.

Sementara itu, yang dimaksud dengan rekonsiliasi dalam konteks konflik atau kekerasan politik, adalah mengembangkan saling penerimaan yang bersifat damai antara orang-orang atau kelompok yang bermusuhan atau dahulunya ber-

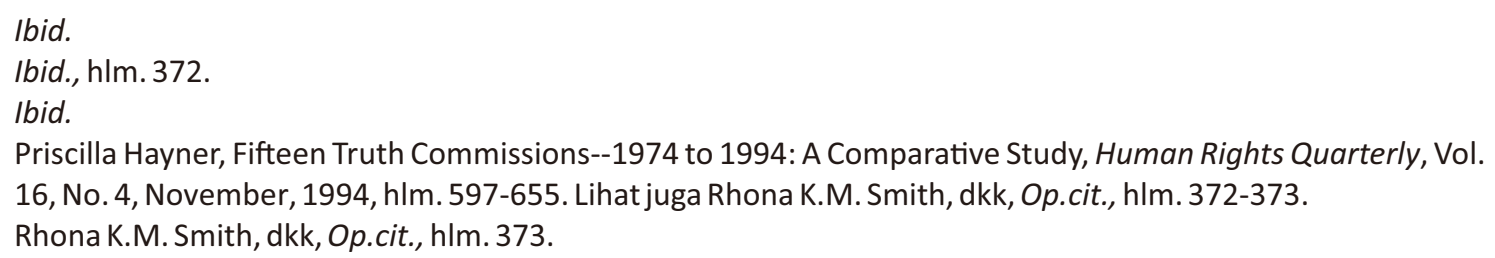


musuhan. ${ }^{16}$ Dengan demikian, rekonsiliasi dalam konteks KKR terkait dengan usaha memperbaiki hubungan sosial, politik, dan psikologis antar warga negara sebagai pribadi atau kelompok dengan negara akibat perlakuan atau tindakan negara yang tidak adil dan tidak manusiawi. Rekonsiliasi itu diperlukan untuk membangun masa depan bangsa dan negara yang demokratis di atas pilihan sikap saling memaafkan atau melupakan, dan bukan penuntutan pidana. ${ }^{17}$

Dalam konteks ini, maka rekonsiliasi mensyaratkan dilakukannya pengungkapan kebenaran. ${ }^{18}$ Karena itu, kebenaran dan rekonsiliasi dianggap sebagai satu kesatuan yang sulit dipisahkan. Kalau dipisahkan akan dapat menimbulkan ketimpangan tertentu, mengingat rekonsiliasi antara pelaku dan korban pelanggaran hak asasi manusia membutuhkan pengungkapan kebenaran di belakang semua kejadian secara menyeluruh. Rekonsiliasi yang mensyaratkan pengungkapan kebenaran ini telah menjadi prinsip dasar KKR di Afrika Selatan. Adapun rekonsiliasi yang dimaksud adalah rekonsiliasi politik nasional, dan bukan rekonsiliasi individual. ${ }^{19}$

Walau demikian, KKR tetap dianggap sebagai salah satu alternatif model penyelesaian pelanggaran HAM berat di masa lalu selain pengadilan. Sebagai salah satu alternatif model, maka KKR bukanlah lawan dari penyelesaian hukum (pengadilan), tetapi 'teman' dari penyelesaian hukum, meskipun dapat memiliki mekanisme dan hasil akhir yang berbeda. ${ }^{20}$

KKR tidak dapat dan tidak boleh menggantikan fungsi pengadilan, karena KKR bukan badan peradilan, KKR bukan persidangan hukum, dan KKR tidak memiliki kekuasaan untuk mengirim seseorang ke penjara atau memvonis seseorang karena suatu kejahatan tertentu. Hanya saja, KKR dapat melakukan beberapa hal penting yang secara umum tidak dapat dicapai melalui proses penuntutan persidangan di pengadilan pidana. ${ }^{21}$

Bahkan KKR dapat saja menangani kasus dalam jumlah relatif lebih besar dibandingkan pengadilan pidana. Dalam suatu situasi di mana terjadi pelanggaran hak asasi manusia berat yang meluas dan sistematis di bawah rezim sebelumnya, KKR dapat menyelidiki semua kasus-kasus atau sejumlah besar kasus yang ada secara komprehensif dan tidak dibatasi kepada penanganan sejumlah kecil kasus saja. $^{22}$

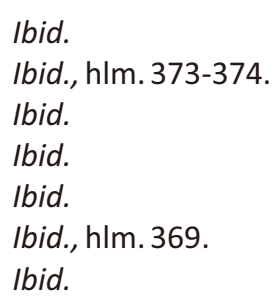




\section{Urgensi Pembentukan UU KKR di Indonesia \\ 1. Kronologis KKR di Indonesia}

Kronologis Komisi Kebenaran dan Rekonsiliasi (KKR) di Indonesia, dapat dilacak dari beberapa peraturan perundang-undangan, khususnya ketika terbentuknya UU KKR sampai kemudian dibatalkan oleh Mahkamah Konstitusi lewat Putusan Nomor 6/PUU-IV/2006. Secara lebih lengkap, Pusat Dokumentasi ELSAM (Lembaga Studi dan Advokasi Masyarakat) menguraikan kronologis UU KKR, sebagai berikut: ${ }^{23}$

- Pada tahun 1998, muncul gagasan membentuk KKR oleh tokoh politik, LSM, dan Komnas HAM. Terjadi Kesepakatan antara Komnas HAM dan Pemerintah untuk membentuk Tim Informal Rekonsiliasi Nasional, dengan beberapa usulan format rekonsiliasi, antara lain Rembuk Nasional, Forum Konsolidasi Nasional, sampai pada Komisi Pencari Kebenaran dan Rekonsiliasi. Pada tahun 2000, pembentukkan KKR mendapatkan payung hukum melalui Ketetapan Majelis Permusyawaratan Rakyat (Tap MPR) Nomor V/MPR/2000 tentang Pemantapan Persatuan Nasional yang dengan tegas memerintahkan dibentuknya KKR. Selain itu pembentukan KKR juga terdapat dalam UU Pengadilan HAM sebagai sebuah mekanisme alternatif penyelesaian pelanggaran HAM masa lalu. Amanat pembentukan KKR dengan undang-undang khusus ini kemudian berlanjut dengan persiapan penyusunan naskah Rancangan Undang-Undang (RUU) oleh Departemen Hukum dan Perundang-Undangan sejak tahun 2000;

- Pada tahun 2001, di tengah pembahasan draf RUU KKR, DPR dan Pemerintah menjanjikan kepada rakyat Papua bahwa negara akan mempertanggungjawabkan berbagai bentuk pelanggaran HAM di Papua melalui dua instrumen, yaitu Pengadilan HAM dan KKR yang dituangkan dalam Undang-Undang Nomor 21 Tahun 2001 tentang Otonomi Khusus Papua (UU Otonomi Khusus Papua). Pasal 44 UU Otonomi Khusus Papua menyatakan KKR dilakukan untuk "melakukan klarifikasi sejarah dan merumuskan serta menetapkan langkah-langkah rekonsiliasi" dalam rangka menjaga persatuan bangsa;

- Pada tahun 2003, pembahasan RUU KKR mulai berjalan di DPR dengan membentuk Panitia Khusus (Pansus) dari lintas fraksi dengan waktu lebih dari satu setengah tahun sampai akhirnya di sahkan menjadi UU. Lamanya pembahasan ini karena terdapat proses Rapat Dengar Pendapat Umum (RDPU) yang mengundang lebih dari 50 kelompok dan indvidu untuk memberikan pandangan tentang KKR;

- Pada tanggal 7 September 2004, RUU KKR disahkan dalam rapat paripurna DPR menjadi UU Komisi Kebenaran dan Rekonsiliasi, dan diundangkan melalui Undang-Undang Nomor 27 Tahun 2004 pada 6 Oktober 2004;

\footnotetext{
ELSAM, Mendorong Pembentukan Kembali UU Komisi Kebenaran dan Rekonsiliasi, Policy Brief, Koleksi Pusat Dokumentasi ELSAM, hlm. 1-4. Dapat diunduh melalui http://referensi.elsam.or.id/2014/09/mendorongpembentukan-kembali-uu-komisi-kebenaran-dan-rekonsiliasi/, diakses 10 November 2016.
} 
- Pasca diundangkan, proses pembentukan KKR berjalan sangat lambat. KKR seharusnya terbentuk pada bulan April 2005 karena UU KKR mengamanatkan pembentukan KKR 6 (enam) bulan setelah UU KKR diundangkan. Pemerintah melalui Departemen Hukum dan HAM baru mulai melakukan proses seleksi calon anggota Komisioner KKR pada April 2005 sampai akhirnya terpilih 42 calon untuk diserahkan kepada Presiden pada Agustus 2005;

- Pada tahun 2006, di tengah keterlambatan pembentukan KKR Nasional, pemerintah menjanjikan kepada rakyat Aceh untuk membentuk KKR sebagai instrumen penyelesaian masalah Hak Asasi Manusia. melalui UU Pemerintah Aceh, Pasal 229 menyatakan bahwa "untuk menyelesaikan pelanggaran HAM di masa lalu di Aceh dibentuk Komisi Kebenaran dan Rekonsiliasi." KKR yang dijanjikan untuk Aceh ini, merupakan bagian dari KKR Nasional. Janji untuk membentuk KKR tersebut juga merupakan hasil perundingan internasional antara RI dengan GAM dalam sebuah MoU yakni dalam MoU Helsinki;

- Pada tahun 2006, terjadi upaya mengajukan uji materiil UU KKR ke Mahkamah Konstitusi (MK) yang diajukan oleh sejumlah LSM dan korban pelanggaran HAM. Para pemohon uji materiil ini mendalilkan bahwa sejumlah ketentuan UU KKR bertentangan dengan UUD 1945, diantaranya mengenai pemberian amnesti kepada pelaku, dan penyelesaian pelanggaran HAM masa lalu yang 'seolah' terjadi tawar menawar dengan pelaku, karena adanya prasyarat rekonsiliasi atau penyelesaian pelanggaran HAM yang berat dilakukan setelah adanya amnesti kepada para pelaku, klausul-klausul tersebut juga dianggap bertentang dengan hukum hak asasi manusia internasional, hukum humaniter, dan bertentangan dengan prinsip-prinsip terkait hak-hak korban;

- Pada akhir tahun 2006, MK tidak hanya mengabulkan tuntutan para pemohon, bahkan justru membatalkan keseluruhan UU KKR. MK berargumen bahwa pasal yang dibatalkan merupakan pasal yang merupakan jantung dari apa yang menjadi tujuan UU KKR. Dengan pembatalan pasal ini maka KKR tidak lagi bisa menjadi tujuannya, sehingga UU KKR perlu dibatalkan secara keseluruhan. MK kemudian merekomendasikan untuk membentuk UU KKR baru sesuai dengan UUD 1945, hukum humaniter, dan hukum hak asasi manusia internasional.

Berdasarkan kronologis UU KKR tersebut, maka keberadaan KKR secara hukum merupakan amanat beberapa peraturan perundang-undangan, yaitu Tap MPR Nomor V/MPR/2000 tentang Pemantapan Persatuan Nasional, UU Pengadilan HAM, UU Otonomi Khusus Papua, dan UU Pemerintah Aceh.

Putusan MK Nomor 6/PUU-IV/2006 walaupun membatalkan UU KKR, tetapi tidak berarti menutup upaya penyelesaian pelanggaran HAM berat di masa lalu melalui upaya rekonsiliasi. Itu artinya, mandat untuk membentuk KKR masih dianggap relevan dan harus tetap dilakukan dengan memperhatikan putusan MK tersebut. Secara lebih eksplisit, hal tersebut disebutkan dalam Putusan MK Nomor 


\section{6/PUU-IV/2006 yang mengatakan:}

"Dengan dinyatakannya UU KKR tidak mempunyai kekuatan hukum mengikat secara keseluruhan, tidak berarti Mahkamah menutup upaya penyelesaian pelanggaran HAM berat di masa lalu melalui upaya rekonsiliasi. Banyak cara yang dapat ditempuh untuk itu, antara lain dengan mewujudkan rekonsiliasi dalam bentuk kebijakan hukum (undang-undang) yang serasi dengan UUD 1945 dan instrumen HAM yang berlaku secara universal, atau dengan melakukan rekonsiliasi melalui kebijakan politik dalam rangka rehabilitasi dan amnesti secara umum."

Putusan MK tersebut menggariskan bahwa upaya mewujudkan rekonsiliasi dapat dilakukan dengan (1) membentuk kebijakan hukum undang-undang yang serasi dengan UUD 1945 dan instrumen HAM yang berlaku secara universal, atau (2) dengan melakukan rekonsiliasi melalui kebijakan politik dalam rangka rehabilitasi dan amnesti secara umum. Dengan demikian pula, pembentukan KKR bukanlah suatu hal yang tabu, melainkan sebuah kewajiban hukum sebagai mandat undangundang.

Bahkan pada tahun 2007, melalui Undang-Undang Nomor 17 Tahun 2007 tentang Rencana Pembangunan Jangka Panjang Nasional, juga disebutkan tentang pentingnya melaksanakan rekonsiliasi nasional untuk menyelesaikan dan menuntaskan persoalan-persoalan yang masih mengganjal pada masa yang lalu, seperti pelanggaran HAM berat dan tindakan-tindakan kejahatan politik yang dilakukan atas nama negara, sebagai salah satu bagian dari konsolidasi demokrasi. Hal ini menunjukkan bahwa dalam rencana pembangunan jangka panjang nasional, upaya untuk melakukan rekonsiliasi akibat dari persoalan-persoalan pelanggaran HAM berat masa lalu menjadi bagian yang integral dalam pembangunan nasional.

Sayangnya Pemerintah dan DPR belum mampu membahas RUU KKR selain hanya dimasukkan dalam program legislasi nasional saja. Hal tersebut dapat dilihat dari Prolegnas Tahun 2007, 2008, dan 2009 yang memasukkan RUU KKR dalam daftar RUU Kumulatif Terbuka Akibat Putusan Mahkamah Konstitusi. ${ }^{24}$ Setelah itu, RUU KKR masuk ke dalam Prolegnas Jangka Panjang 2010-2014 dengan nomor urut 93 dan Prolegnas Jangka Panjang 2015-2019 dengan nomor urut 57. ${ }^{25}$ RUU KKR sempat masuk Prolegnas prioritas tahun 2011 dengan nomor urut 51 dengan yang bertanggung jawab membuat draf naskah akademik dan draf RUU adalah Pemerintah. ${ }^{26}$ Namun sampai dengan tahun 2014, Pemerintahan Susilo Bambang

24 BPHN, Tiga Dekade Prolegnas Dan Peran BPHN, Jakarta: BPHN, 2008, hlm. 118. Lihat juga Badan Legislasi DPR RI, Evaluasi Program Legislasi Nasional, RUU Prioritas Tahun 2008, dan Rencana Penyusunan Prolegnas Prioritas Tahun 2009, naskah diproses oleh Pusat Studi dan Kebijakan (PSHK) Indonesia dan ditampilkan di www.parlemen.net, diakses 14 November 2016.

25 Lihat daftar Prolegnas Tahun 2010-2014 dan Prolegnas Tahun 2015-2019.

26 Lihat daftar Prolegnas Prioritas Tahun 2011. 
Yudhoyono gagal memasukkan draf RUU KKR untuk dibahas bersama DPR. Pada tahun 2015, RUU KKR kembali masuk ke dalam Prolegnas Prioritas dengan nomor urut 13 , dengan penanggung jawab penyusun draf RUU dan draf naskah akademik adalah pemerintah. ${ }^{27}$ Namun, sampai dengan tahun 2016, Pemerintahan Joko Widodo belum juga memasukkan draf RUU KKR untuk kemudian dibahas bersama DPR. Dan sayangnya pada tahun 2017, RUU KKR tidak masuk daftar Prolegnas Prioritas. ${ }^{28} \mathrm{Hal}$ ini menunjukkan komitmen dan political will pemerintah dan DPR dalam menyelesaikan RUU KKR sangatlah rendah.

Hal yang menarik berkaitan dengan karakter umum yang diungkapkan Priscilla Hayner bahwa KKR terbentuk beberapa saat setelah rezim otoriter tumbang. ${ }^{29}$ Dalam konteks Indonesia saat ini, Rezim Orde Baru yang dianggap sebagai rezim otoriter telah tumbang pada tahun 1998, oleh karena itu pembentukan KKR melalui UU KKR dianggap masih relevan karena rentang waktu yang belum begitu lama (enam tahun). Namun, hal berbeda ketika tahun tahun 2016 yang artinya telah 18 tahun rezim otoriter tumbang, akan tetapi KKR belum juga dibentuk apalagi dilakukan. Karenanya menjadi pertanyaan kemudian apakah rentang waktu 18 tahun bahkan berpotensi lebih tersebut dapat dikatakan sebagai waktu yang masih tepat untuk melakukan pengungkapan kebenaran dan rekonsiliasi melalui KKR. Walau bagaimanapun juga, upaya penyelesaian pelanggaran HAM berat di masa lalu haruslah tetap dilakukan, agar tidak menjadi janji yang terus menjadi hutang dan tanggungan beban di masa yang akan datang. Inilah mungkin salah bentuk anomali upaya pembentukan KKR di Indonesia yang tidak sesuai dengan karakter umum terbentuk beberapa saat setelah rezim otoriter tumbang sebagaimana disebutkan Prisciilla Hayner.

\section{Upaya Rekonsiliasi Tanpa Pengungkapan Kebenaran dan UU KKR}

Sebagaimana telah disebutkan, Pemerintahan Joko Widodo saat ini telah membentuk tim gabungan untuk menyelesaikan kasus pelanggaran HAM berat masa lalu yang terdiri dari Komnas HAM, Kementerian Kordinator Politik Hukum dan Keamanan, Kejaksaan Agung, Kementerian Hukum dan HAM, Polri, dan TNI pada Mei 2015. Jalur rekonsiliasi ini memunculkan opsi antara meminta maaf atau penyesalan yang akan dilakukan oleh Pemerintahan Joko Widodo terhadap pelanggaran HAM berat masa lalu tersebut.

Berbagai alasan dan pertimbangan dikemukakan Pemerintahan Joko Widodo. Misalnya yang disebutkan Menteri Koordinator Politik, Hukum, dan Keamanan, Luhut Binsar Pandjaitan ${ }^{30}$ pada awal 2016 yang mengatakan pernyataan penyesalan

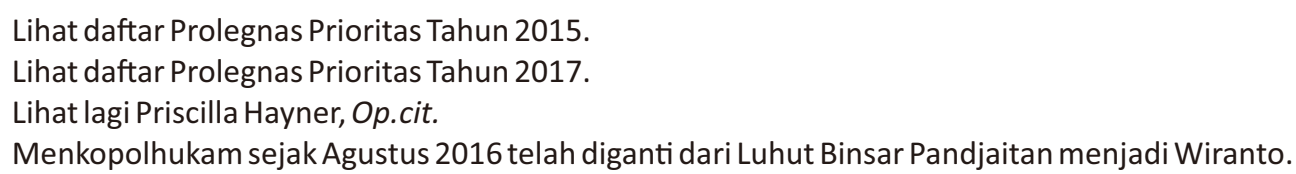


dipilih untuk mengganti permintaan maaf pemerintah terhadap keluarga korban kejahatan HAM. ${ }^{31}$ Selain memberikan pernyataan menyesal, menurut Luhut, pemerintah juga tengah menyiapkan langkah lainnya untuk menuntaskan kasus HAM di mana di antara opsi itu, pemerintah dipastikan tidak akan memberikan ganti rugi kepada keluarga korban. Menurut Luhut karena hal tersebut akan sulit, menentukan siapa yang jadi korban, siapa yang mengganti, sehingga akan repot. Karenanya menurut Luhut, pemerintah dapat melihat dalam konteks penyesalan yang mendalam. ${ }^{32}$

Sementara itu, Jaksa Agung M. Prasetyo menuturkan pendekatan non-yudisial dilakukan dengan rekonsiliasi dengan keluarga korban. Cara ini dipilih pemerintah dari pada merealisasikan Pengadilan HAM Ad hoc karena tantangan dalam mengusut kembali kasus-kasus itu. ${ }^{33}$ Menurut Prasetyo, sulit menyelidiki kembali kasus-kasus HAM masa lalu ini karena saksi-saksi yang sudah tidak ada. Karenanya penyelesaian dengan rekonsiliasi dianggap akan lebih efektif dan lebih tepat supaya bangsa ini tidak tersandera oleh beban salah masa lalu. ${ }^{34}$

Opsi permintaan maaf tersebut sempat mengemuka dan menjadi isu yang beredar dipublik, terutama berkaitan dengan Pelanggaran HAM berat tahun 19651966. Hal ini berkaitan dengan diserahkannya hasil Pengadilan Rakyat Internasional atau International People Tribunal (IPT) 1965 di Den Haag Belanda kepada Komisi Nasional Hak Asasi Manusia (Komnas HAM) pada November 2015 yang menyatakan pemerintah Indonesia harus bertanggung jawab atas kejahatan kemanusiaan pasca gerakan 30 September $1965 .{ }^{35}$ Isu yang kemudian menimbulkan pro dan kontra ditengah-tengah masyarakat karena persitiwa 1965-1966 mengandung dimensi sosial, politik dan ideologi yang sangat kuat, yaitu berkaitan dengan Partai Komunis Indonesia (PKI), ${ }^{36}$ sehingga opsi permintaan maaf belum dilakukan oleh pemerintah.

Selain kasus 1965, sebagaimana telah disebutkan tim gabungan juga membidik beberapa dugaan pelanggaran HAM berat lainnya. Jika jalur rekonsiliasi hendak ditempuh oleh Presiden Joko Widodo ini tidak dibarengi dengan upaya melakukan pengungkapan kebenaran, maka ini yang akan menjadi persoalan. Sebagaimana telah disebutkan, pengalaman banyak negara menunjukkan kesuksesan rekonsiliasi juga sangat bergantung dari upaya untuk mengungkapkan kebenaran. Apalagi

\footnotetext{
Kompas, "Pemerintah Pilih Nyatakan Penyelesalan Ketimbang Minta Maaf di Kasus HAM Berat", http://nasional.kompas.com/read/2016/01/05/20444951/Pemerintah.Pilih.Nyatakan.Penyesalan.Ketimban g.Minta.Maaf.di.Kasus.HAM.Berat, diakses 16 November 2016.

Ibid.

Ibid.

Ibid.

Liputan 6, "Komnas HAM Janji Tindak Lanjuti Putusan Tragedi 65", http://news.liputan6.com/read/2561214/komnas-ham-janji-tindak-lanjuti-putusan-tragedi-65, diakses 16 November 2016.

36 BBC Indonesia, "Pro Kontra Permintaan Maaf Kepada Korban Tragedi 1965", http://www.bbc.com¿indonesia/berita indonesia/2015/09/150925 indonesia lapsus pemerintah maaf, diakses 16 November 2016.
} 
rekonsiliasi yang hendak dicapai dan dituju bukanlah rekonsiliasi individual, melainkan rekonsiliasi politik secara nasional, sehingga pengungkapan kebenaran terhadap pelanggaran-pelanggaran HAM berat masa lalu di Indonesia sudah menjadi keharusan yang melekat dalam upaya melakukan rekonsiliasi tersebut.

Upaya melakukan rekonsiliasi tanpa pengungkapan kebenaran akan dapat mengancam kesuksesan rekonsiliasi, sebagaimana dikatakan Rhona K.M. Smith, $\mathrm{dkk} \cdot:^{37}$

"Ide dasar konsep KKR didasarkan pada sebuah kepercayaan 'rekonsiliasi antara pelaku dan korban pelanggaran hak asasi manusia membutuhkan pengungkapan kebenaran di belakang semua kejadian secara menyeluruh'. Memberikan kesempatan kepada korban untuk bicara dan menerima penjelasan tentang kejadian-kejadian penting yang berhubungan dengan pelanggaran hak asasi manusia di masa lalu adalah hal yang penting. Karenanya, diharapkan hal ini dapat meletakkan fondasi terungkapnya kebenaran demi tegaknya keadilan, yang pada gilirannya tercapai rekonsiliasi.

.... Ada banyak kekeliruan tafsir atas KKR, bahwa KKR seolah-olah hanya mengedepankan rekonsiliasi, padahal yang utama dan diutamakan dalam KKR adalah mengungkapkan kebenaran demi kebenaran itu sendiri dalam rangka memberikan keadilan bagi korban. Kebenaran yang terungkap dan keadilan yang diberikan adalah jalan masuk bagi terciptanya rekonsiliasi."

Hal tersebut juga sejalan dengan pendapat Herlambang saat memberikan catatan untuk UU KKR, dengan mengatakan: ${ }^{38}$

"Kelebihan yang dimiliki oleh dibentuknya KKR adalah (1) Memberi arti kepada suara korban secara individual; (2) Adanya pelurusan sejarah berkaitan dengan peristiwa-peristiwa pelanggaran HAM; (3) Pendidikan dan pengetahuan publik; (4) Memeriksa pelanggaran HAM Sistematis Menuju Reformasi Kelembagaan; (5) Memberikan penilaian dan pembelajaran tentang akibat pelanggaran HAM terhadap korban; dan (6) Adanya pertanggungjawaban para pelaku kejahatan HAM berat. Yang terpenting dalam mekanisme KKR ini adalah penghormatan terhadap korban yang diwujudkan dalam bentuk pengungkapan kebenaran fakta-fakta masa lalu dan pengakuan para pelaku kejahatan HAM, sebagai prasyarat menuju rekonsiliasi. Adalah tidak mungkin membentuk peradaban suatu bangsa, yang kerap bangga didengung-

Rhona K.M. Smith, dkk., Op.cit., hlm. 374.

Dalam R. Herlambang Perdana Wirataman dalam Akses Keadilan Bagi Korban Pelanggaran Hak Asasi Manusia Berat Pasca Putusan Mahkamah Konstitusi Nomor 006/PUU-IV/2006, Jurnal Rechtsvinding, Vol. 2 No. 2, Agustus 2013, hlm. 178-179. 
dengungkan 'nation building' oleh penguasa, tanpa menjelaskan ada apa sebenarnya yang terjadi di masa lalu dan berupaya menyelesaikannya. Tanpa itu, maka bayang-bayang gelap masa lalu senantiasa membayangi dan menyulitkan keinginan membangun peradaban yang lebih baik."

Dengan melihat argumentasi tersebut, maka upaya yang dilakukan tim gabungan yang dibentuk Pemerintahan Joko Widodo tersebut, seharusnya tidak berlindung pada alasan kesulitan karena tidak adanya saksi yang masih hidup ataupun alat alat bukti yang hilang, sehingga berupaya melakukan rekonsiliasi tanpa melakukan pengungkapan kebenaran secara jujur. Walau bagaimanapun, upaya rekonsiliasi seharusnya tetap mengedepankan upaya pencarian kebenaran terlebih dahulu, sehingga tidak menimbulkan cacat bawaan karena adanya paksaan.

Selain itu, jika dilihat kebijakan Pemerintahan Joko Widodo tersebut merupakan kebijakan yang diambil tanpa membentuk terlebih dahulu payung hukum berupa undang-undang. Hal inilah yang menjadi pertanyaan, apakah kebijakan tersebut merupakan tafsir atas Putusan MK Nomor 6/PUU-IV/2006 yang mengatakan "Dengan dinyatakannya UU KKR tidak mempunyai kekuatan hukum mengikat secara keseluruhan, tidak berarti Mahkamah menutup upaya penyelesaian pelanggaran HAM berat di masa lalu melalui upaya rekonsiliasi. Banyak cara yang dapat ditempuh untuk itu, antara lain dengan mewujudkan rekonsiliasi dalam bentuk kebijakan hukum (undang-undang) yang serasi dengan UUD 1945 dan instrumen HAM yang berlaku secara universal, atau dengan melakukan rekonsiliasi melalui kebijakan politik dalam rangka rehabilitasi dan amnesti secara umum" (garis tebal penulis). Jika frasa terakhir yang menyatakan "atau dengan melakukan rekonsiliasi melalui kebijakan politik dalam rangka rehabilitasi dan amnesti secara umum", yang dijadikan rujukan dalam pengambilan kebijakan oleh Pemerintahan Joko Widodo, maka sebenarnya ini merujuk pada kewenangan konstitusional Presiden yang diatur dalam Pasal 14 UUD 1945 Setelah Perubahan, yang menyebut: (1) Presiden memberi grasi dan rehabilitasi dengan memperhatikan pertimbangan Mahkamah Agung; (2) Presiden memberi amnesti dan abolisi dengan memperhatikan Dewan Perwakilan Rakyat. ${ }^{39}$

\footnotetext{
Grasi, amnesti, abolisi dan rehabilitasi menurut Bagir Manan merupakan kekuasaan Presiden dalam bidang yudisial karena tidak dapat dipisahkan, baik secara langsung atau tidak langsung dari proses yustisial, walaupun tidak termasuk ke dalam bentuk upaya hukum. Grasi adalah kewenangan Presiden memberi pengampunan dengan cara meniadakan atau mengubah atau mengurangi pidana bagi seorang yang dijatuhi pidana dan telah memperoleh kekuatan hukum tetap. Amnesti adalah kewenangan Presiden meniadakan sifat pidana atas perbuatan seseorang atau kelompok orang, sehingga mereka yang terkena amnesti dipandang tidak pernah melakukan suatu perbuatan pidana. Abolisi adalah kewenangan Presiden meniadakan tuntutan. Rehabilitasi adalah pengembalian pada kedudukan atau keadaan semula sebelum atau sesudah seseorang dijatuhi pidana atau dikenai pidana. Lihat Bagir Manan, Lembaga Kepresidenan, Yogyakarta: FH UII Press, 2006, hlm. 158-159.
} 
Walaupun rehabilitasi dan amnesti secara umum merupakan hak atau kewenangan konstitusional Presiden, namun dalam tataran praktis tidaklah mudah. Jika mengambil contoh Keputusan Presiden Nomor 22 Tahun 2005 tentang Pemberian Amnesti Umum dan Abolisi kepada Setiap Orang yang Terlibat dalam Gerakan Aceh Merdeka, yang ditandatangani Presiden Soesilo Bambang Yudohono pada 30 Agustus 2005, tidak serta merta membuat tuntutan pembentukan KKR di Aceh berhenti. Bahkan UU Pemerintahan Aceh yang disahkan setahun setelah pemberian amnesti umum dan abolisi kepada setiap orang yang terlibat dalam Gerakan Aceh Merdeka tersebut, tetap mengamanatkan pembentukan KKR di Aceh. Hal ini menunjukkan bahwa pemberian amnesti umum belum dapat menyelesaikan pelanggaran HAM berat di masa lalu karena tidak disertai dengan pengungkapan kebenaran. Dengan demikian upaya rekonsiliasi secara komprehensif sulit tercapai.

Selain dari aspek praktis tersebut, dari sisi peraturan perundang-undangan, upaya membentuk tim gabungan rekonsiliasi namun tidak disertai dengan payung hukum berupa UU KKR akan dapat menimbulkan persoalan hukum. Hal tersebut dilihat dengan pendekatan sistematis ${ }^{40}$ beberapa peraturan perundang-undangan yang berlaku di Indonesia, yaitu:

Pertama, dalam UUD 1945, Pasal 28J ayat (2) menyebutkan:

"Dalam menjalankan hak dan kebebasannya, setiap orang wajib tunduk kepada pembatasan yang ditetapkan dengan undang-undang dengan maksud semata-mata untuk menjamin pengakuan serta penghormatan atas hak dan kebebasan orang lain dan untuk memenuhi tuntutan yang adil sesuai dengan pertimbangan moral, nilai-nilai agama, keamanan dan ketertiban umum dalam suatu masyarakat demokratis."

Ketentuan ini menunjukkan bahwa bentuk hukum undang-undanglah yang paling tepat dalam hal mengatur kewajiban, pembatasan hak asasi manusia, apalagi berkaitan dengan keamanan dan ketertiban umum. Dalam hal rekonsiliasi dalam upaya penuntasan pelanggaran HAM berat di masa lalu, tentu akan sangat berkaitan dengan pembatasan HAM, keamanan, dan ketertiban umum, karena dapat saja pihak pelaku yang dulu melakukan pelanggaran HAM berat adalah aparat negara sehingga pengungkapan kebenaran dan rekonsiliasi dapat memperoleh tantangan baik secara individual maupun secara kelembagaan yang mengganggu keamanan dan ketertiban umum.

\footnotetext{
Pendekatan sistematis yang dimaksud di sini adalah pendekatan penafsiran sistematis. Menurut Sudikono Mertokusumo dan A. Pitlo, penafsiran sistematis menuntut kita harus membaca undang-undang dalam keseluruhannya, tidak boleh mengeluarkan suatu ketentuan lepas dari keseluruhannya, tetapi harus meninjaunya dalam hubungannya dengan ketentuan sejenis. Antara banyak peraturan terdapat hubungan, yang satu timbul dari yang lain. Seluruhnya merupakan satu sistem besar. Lihat Sudikno Mertokusumo dan A. Pitlo, Bab-Bab Tentang Penemuan Hukum, Bandung: Citra Aditya Bakti, 1993, hlm. 60.
} 
Kedua, terdapat ketentuan undang-undang yang secara tegas memerintahkan langsung pembentukan KKR yang bentuk hukumnya undang-undang. Misalnya, UU Pengadilan HAM, dalam Pasal 47 disebutkan: “(1) Pelanggaran hak asasi manusia yang berat yang terjadi sebelum berlakunya Undang-Undang ini tidak menutup kemungkinan penyelesaiannya dilakukan oleh Komisi kebenaran dan Rekonsiliasi, (2) Komisi kebenaran dan Rekonsiliasi sebagaimana dimaksud dalam ayat (1) dibentuk dengan Undang-undang."

Ketiga, berkaitan dengan pelaksanaan pengungkapan kebenaran dan upaya rekonsiliasi akan berkaitan erat dengan upaya hukum di pengadilan bahkan mungkin saja mengecualikannya. Hal tersebut diatur dalam berbagai macam undang-undang, seperti KUHP dan KUHAP. Selain itu, lembaga-lembaga yang akan diperiksa demi mengungkap kebenaran seperti Kepolisian dan TNI yang diatur juga dalam undang-undang. Dengan demikian, pengungkapan kebenaran dan upaya rekonsiliasi tidak mungkin dilakukan tanpa dasar hukum setingkat undang-undang sebagai lex specialis dari berbagai macam undang-undang yang berkaitan tersebut. Apalagi jika kemudian dasar hukumnya di bawah undang-undang yang secara hierarki peraturan perundang-undangan tidak dapat mengecualikan peraturan perundang-undangan diatasnya sesuai prinsip lex superior derogat lex inferior. Sesuai dengan Undang-Undang Nomor 12 Tahun 2011 tentang Pembentukan Peraturan Perundang-Undangan (UU P3-U), posisi Qanun Aceh adalah sederajat dengan Peraturan Daerah Tingkat Provinsi. Dengan demikian, maka secara hirarki peraturan perundang-undangan Qanun Aceh berada dibawah undang-undang. ${ }^{41}$

Keempat, jika dikaitkan dengan UU P3-U, Pasal 10 Ayat (1) menyebutkan bahwa materi muatan yang harus diatur dengan Undang-Undang berisi: (a) pengaturan lebih lanjut mengenai ketentuan Undang-Undang Dasar Negara Republik Indonesia Tahun 1945; (b) perintah suatu Undang-Undang untuk diatur dengan UndangUndang; (c) pengesahan perjanjian internasional tertentu; (d) tindak lanjut atas putusan Mahkamah Konstitusi; dan/atau (e) pemenuhan kebutuhan hukum dalam masyarakat. Berdasarkan hal tersebut, maka dapat dikatakan pembentukan KKR dalam bentuk Undang-Undang memenuhi materi muatan sebagaimana dimaksud Pasal 10 Ayat (1) huruf a, b, d, dan e. Apalagi jika dikaitkan dengan doktrin yang diajarkan Bagir Manan yang menyebutkan bahwa dalam pembentukan peraturan perundang-undangan yang baik, harus memenuhi dasar yuridis, salah satunya

\footnotetext{
Pasal 7 Ayat (1) UU Nomor 12 Tahun 2011 tentang Pembentukan Peraturan Perundang-Undangan menyebutkan jenis dan hierarki Peraturan Perundang-Undangan terdiri atas: a. Undang-Undang Dasar Negara Republik Indonesia Tahun 1945; b. Ketetapan Majelis Permusyawaratan Rakyat; c. Undang-Undang/Peraturan Pemerintah Pengganti Undang-Undang; d. Peraturan Pemerintah; e. Peraturan Presiden; f. Peraturan Daerah Provinsi; dan g. Peraturan Daerah Kabupaten/Kota. Penjelasan Pasal 7 Ayat (1) huruf $f$ menyebutkan: "Termasuk dalam Peraturan Daerah Provinsi adalah Qanun yang berlaku di Provinsi Aceh dan Peraturan Daerah Khusus (Perdasus) serta Peraturan Daerah Provinsi (Perdasi) yang berlaku di Provinsi Papua dan Provinsi Papua Barat.
} 
adalah keharusan adanya kesesuian bentuk atau jenis peraturan perundangundangan dengan materi yang diatur, terutama kalau diperintahkan oleh peraturan

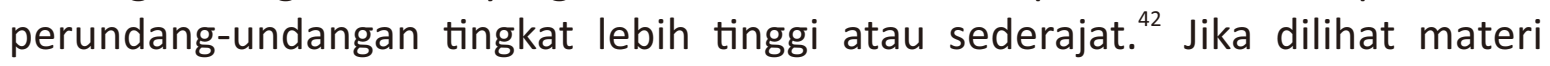
muatan yang hendak diatur adalah rekonsiliasi dalam upaya penuntasan pelanggaran HAM berat di masa lalu. Materi muatan tersebut jelas menyangkut hak dasar atau hak asasi, yang menurut Bagir Manan dan Kuntana Magnar merupakan salah satu materi muatan undang-undang. ${ }^{43}$ Hal yang sama juga disebutkan Hamid Attamimi ${ }^{44}$ dan Maria Farida Indrati ${ }^{45}$ yang menyebut salah satu materi muatan undang-undang adalah berkenaan dengan HAM. Materi muatan hak asasi dalam undang-undang tersebut berkaitan erat dengan paham kedaulatan rakyat, rakyat yang memerintah dan mengatur diri sendiri. Karenanya hanya rakyat yang dapat menentukan pembatasan terhadap diri mereka sendiri, termasuk pembatasan atas hak asasinya. ${ }^{46}$ Selain itu, Bagir Manan dan Kuntana Magnar juga menyebutkan materi muatan undang-undang adalah yang menyangkut kepentingan atau kewajiban rakyat banyak. ${ }^{47}$ KKR sebagaimana telah disebut merupakan tindakan kolektif yang menyangkut kepentingan rakyat banyak dalam upaya melakukan rekonsiliasi atas pelanggaran HAM berat di masa lalu, bukan kepentingan individual.

Kelima, jika dikaitkan dengan amanat membentuk KKR di daerah yaitu di Papua melalui UU Otonomi Khusus Papua dan UU Pemerintahan Aceh. Pembentukan KKR di daerah tanpa ada payung hukum KKR di tingkat nasional akan sangat menyulitkan, mengingat ketentuan KKR baik dalam UU Otonomi Khusus Papua dan UU Pemerintahan Aceh tersebut masih sangat umum. Misalnya dalam Pasal 45 Ayat UU Otonomi Khusus Papua menyebutkan "Untuk melaksanakan kewajiban menegakkan, memajukan, melindungi, dan menghormati HAM di Provinsi Papua, dibentuk perwakilan Komnas HAM, Pengadilan HAM, dan KKR di Provinsi Papua sesuai dengan peraturan perundang-undangan". Selanjutnya, Pasal 46 menyebutkan KKR di Provinsi Papua dibentuk untuk pemantapan persatuan dan kesatuan bangsa dengan tugas: (a) melakukan klarifikasi sejarah Papua untuk pemantapan persatuan dan kesatuan bangsa dalam Negara Kesatuan Republik Indonesia; dan (b) merumuskan dan menetapkan langkah-langkah rekonsiliasi.

Lima hal tersebut ditambah juga dengan alasan praktis yang telah disebutkan, kiranya sudah cukup menjadi alasan bahwa pembentukan UU KKR di tingkat

Bagir Manan, Dasar-Dasar Perundang-Undangan Indonesia, Jakarta: Ind-Hill.Co, 1992, hlm. 14.

43 Bagir Manan dan Kuntana Magnar, Beberapa Masalah Hukum Tata Negara Indonesia, Bandung: Alumni, 1997, hlm. 149.

44 A. Hamid Attamimi, Peranan Keputusan Presiden Republik Indonesia dalam Penyelenggaraan Pemerintahan Negara, Disertasi, Pascasarjana Universitas Indonesia, Jakarta, 1990, hlm. 219.

45 Maria Farida Indrati S., Ilmu Perundang-undangan: Jenis Fungsi, dan Materi Muatan, Yogyakarta: Penerbit Kanisius, 2007, hlm. 247.

46 Bagir Manan dan Kuntana Magnar, Op.cit.

47 Ibid. 
nasional memiliki urgensi yang sangat penting dan mendesak demi penuntasan pelanggaran HAM berat di masa lalu. Dengan demikian, masa transisi dalam penuntasan pelanggaran HAM berat di masa lalu tidak semakin berlarut-larut yang menjadi hutang setiap pemerintahan.

\section{Implikasi Ketiadaan UU KKR terhadap KKR Aceh}

Pemerintahan Daerah Provinsi Aceh pada 31 Desember 2013 telah mengesahkan Qanun KKR Aceh. Pengesahan Qanun tersebut merupakan perintah Pasal 229 UU Pemerintahan Aceh yang menyebutkan "untuk mencari kebenaran dan rekonsiliasi, dengan Undang-Undang ini dibentuk Komisi Kebenaran dan Rekonsiliasi di Aceh". Pembentukan KKR Aceh tersebut juga sejalan dengan amanah perjanjian damai yang tertuang dalam Nota Kesepahaman antara Pemerintah Republik Indonesia dan Gerakan Aceh Merdeka yang dikenal dengan MoU Helsinki pada 15 Agustus 2005. Walaupun jika dilihat dari aspek waktu pelaksanaan, Pasal 260 UU Pemerintahan Aceh sebenarnya memerintahkan KKR di Aceh berlaku efektif paling lambat 1 (satu) tahun sejak UU Pemerintahan Aceh diundangkan. Karenanya, terbentuknya Qanun KKR Aceh pada tahun 2013 sebenarnya sudah terlambat 6 (enam) tahun dari waktu yang ditentukan.

Jika ditelisik pengaturan dalam UU Pemerintahan Aceh tersebut, KKR Aceh merupakan bagian tidak terpisahkan dengan Komisi Kebenaran dan Rekonsiliasi (Pasal 229 Ayat (2)). Ketentuan ini sebenarnya menegaskan bahwa KKR Aceh tidak dapat dipisahkan dari KKR yang bersifat nasional. Apalagi Pasal 229 Ayat (3) juga menyebutkan KKR Aceh harus sesuai dengan ketentuan peraturan perundangundangan (dalam Penjelasannya, yang dimaksud dengan peraturan perundangundangan dalam ketentuan ini adalah ketentuan di dalam UU KKR). Karenanya sebagaimana telah disinggung, KKR di tingkat daerah akan sangat sulit dalam melaksanakan tugasnya tanpa adanya KKR di tingkat nasional yang dibentuk berdasarkan undang-undang.

Kesulitan-kesulitan yang mungkin timbul adalah karena ruang lingkup KKR Aceh hanya berlaku di tingkat Provinsi Aceh, sehingga upaya mengungkap kebenaran sebagai jalan menuju rekonsiliasi yang berada diluar Provinsi Aceh sangat mungkin sulit dilakukan. Misalnya dalam Pasal 10 Qanun KKR Aceh tersebut menyebutkan beberapa kewenangan KKR Aceh, seperti dapat mengakses sumber informasi yang diperlukan untuk penyelidikan dalam bentuk dokumen tertulis ataupun keterangan lisan yang berasal dari institusi pemerintah maupun non pemerintah, maupun mendapatkan keterangan atau pernyataan dari setiap orang atau institusi yang terkait dengan peristiwa yang sedang diselidiki. Menjadi pertanyaan jika institusi pemerintah yang dimaksud berada di pusat dan ternyata menyatakan tidak bersedia menyerahkan informasi, apakah Qanun Aceh tersebut dapat memaksa instansi pemerintah yang berada di pusat? Hal inilah yang dimaksud bahwa Qanun 
Aceh tersebut tidak dapat menjadi dasar hukum yang kuat untuk dapat memaksa keluar Aceh.

Hal sama juga dalam mekanisme rekonsiliasi yang diatur dalam Pasal 34 dan 36 Qanun KKR Aceh, yang menyebutkan adanya mekanisme pelaku memohon maaf kepada korban secara terbuka dan dijawab dengan pernyataan penerimaan maaf oleh perwakilan korban secara terbuka, di mana pernyataan permohonan maaf harus dilakukan secara individual dan kesediaan pelaku untuk membayar restitusi. Mekanisme rekonsiliasi ini juga akan sangat sulit dilakukan khususnya jika pelanggaran HAM berat di Aceh dilakukan oleh pihak-pihak diluar Aceh apalagi sampai dengan membayar restitusi.

Dengan demikian, dapat dikatakan hubungan antara KKR Aceh dengan UU KKR tingkat nasional sangatlah erat kaitannya. Akibat ketiadaan UU KKR, pelaksanaan KKR Aceh sangat mungkin sulit dilakukan karena benturan dengan peraturan perundang-undangan lain yang terkait dalam hal upaya pengungkapan kebenaran dan upaya melakukan rekonsiliasi. Karenanya, apa yang dikatakan perwakilan Menteri Dalam Negeri yang menyebutkan KKR Aceh seharusnya menunggu UU KKR nasional adalah tepat. Walau demikian, ketika Pemerintah Pusat melalui Kementerian Dalam Negeri melakukan evaluasi berupa pembatalan terhadap 3143 Peraturan Daerah maupun Peraturan Kepala Daerah pada tahun 2016, Qanun KKR Aceh tidak termasuk ke dalam perda yang dibatalkan. ${ }^{48}$ Hal ini dapat dimaklumi karena Qanun KKR Aceh tersebut mengandung dimensi politik kedaerahan yang kuat, sehingga jika dibatalkan akan menimbulkan resistensi. Karenanya dapat dikatakan bahwa KKR Aceh seolah sengaja dibiarkan hidup namun sebenarnya mati suri, ada namun tidak dapat dilaksanakan (non executable).

\section{E. Penutup}

Pembentukan UU KKR yang sejalan dengan UUD 1945 dan instrumen HAM yang berlaku secara universal sangat urgen dan mendasar sebagai upaya penuntasan pelanggaran HAM berat di masa lalu. Pembentukan UU KKR tersebut merupakan amanat peraturan perundang-undangan yang semestinya dijalankan. Tanpa adanya UU KKR tersebut, maka upaya rekonsiliasi yang dilakukan pemerintah akan mengalami problem hukum yang pada gilirannya akan semakin menunda penuntasan pelanggaran HAM berat di masa lalu. Salah satu akibat ketiadaan UU KKR, membuat KKR Aceh yang dibentuk melalui Qanun KKR seolah mati suri karena dalam menjalankan tugas dan kewenangannya akan berbenturan dengan berbagai macam peraturan perundang-undangan yang terkait dalam hal upaya pengungkapan kebenaran dan upaya melakukan rekonsiliasi. Hal tersebut menunjukkan

\footnotetext{
Lihat Kementerian Dalam Negeri Republik Indonesia, Daftar Perda/Perkada dan Peraturan Menteri Dalam Negeri Yang Dibatalkan/Revisi, 2016.
} 
adanya hubungan yang saling berkaitan antara KKR Aceh dengan UU KKR. Karenanya, Pemerintah dan DPR seharusnya meningkatkan komitmen dan political will-nya untuk segera melakukan pembahasan RUU KKR, dan segera menghilangkan kebiasaan yang hanya memasukkan RUU KKR dalam daftar program legislasi nasional.

\section{Daftar Pustaka}

\section{Buku}

Bagir Manan, Dasar-Dasar Perundang-Undangan Indonesia, Ind-Hill.Co, Jakarta, 1992. , Lembaga Kepresidenan, FH UII Press, Yogyakarta, 2006.

Bagir Manan dan Kuntana Magnar, Beberapa Masalah Hukum Tata Negara Indonesia, PT Alumni, Bandung, 1997.

BPHN, Tiga Dekade Prolegnas Dan Peran BPHN, BPHN, Jakarta, 2008.

Maria Farida Indrati S., IImu Perundang-undangan: Jenis Fungsi, dan Materi Muatan, Penerbit Kanisius, Yogyakarta, 2007.

Rhona K.M. Smith, dkk, Hukum Hak Asasi Manusia, Pusham Ull, Yogyakarta, 2010.

Satya Arinanto, Hak Asasi Manusia dalam Transisi Politik Di Indonesia, PSHTN FH UI, Jakarta, 2008.

Sudikno Mertokusumo dan A. Pitlo, Bab-Bab Tentang Penemuan Hukum, Citra Aditya Bakti, Bandung, 1993.

\section{Dokumen Lain}

A. Hamid Attamimi, Peranan Keputusan Presiden Republik Indonesia dalam Penyelenggaraan Pemerintahan Negara, Disertasi, Pascasarjana Universitas Indonesia, Jakarta, 1990.

Badan Legislasi DPR RI, Evaluasi Program Legislasi Nasional, RUU Prioritas Tahun 2008, dan Rencana Penyusunan Prolegnas Prioritas Tahun 2009, naskah diproses oleh Pusat Studi dan Kebijakan (PSHK) Indonesia dan ditampilkan di www.parlemen.net, diakses 14 November 2016.

BBC Indonesia, "Kemendagri Pertanyakan KKR Aceh", http://www.bbc.com/indonesia/-berita indonesia/2013/12/131227 kemendagri pertanyakan kkraceh, diakses 6 November 2016.

BBC Indonesia, "Pro Kontra Permintaan Maaf Kepada Korban Tragedi 1965", http://www.bbc.com-/indonesia/berita indonesia/2015/09/150925 indonesia lap-sus pemerintah maaf, diakses 16 November 2016.

CNN Indonesia, "Jaksa Agung Ada Titik Terang Dalam Kasus HAM Masa Lalu", http://www.cnnindonesia.com/nasional/20150702144002-12-63889/jaksaagung-ada-titik-terang-dalam-kasus-ham-masa-lalu/, diakses 5 November 2016. 
ELSAM, Mendorong Pembentukan Kembali UU Komisi Kebenaran dan Rekonsiliasi, Policy Brief, Koleksi Pusat Dokumentasi ELSAM, diunduh melalui http://referensi.elsam.or.id/2014/09/mendorong-pembentukan-kembali-uukomisi-kebenaran-dan-rekonsiliasi/, diakses 10 November 2016.

Firdiansyah, Peran dan Harapan Korban untuk Penyelesaian Pelanggaran Berat HAM Masa Lalu, Jurnal HAM Komnas HAM, 2016, diakses 5 November 2016.

Jokowi dan Jusuf Kalla, Jalan Perubahan Untuk Indonesia Yang Berdaulat, Mandiri dan Berkepribadian, Visi, Misi, dan Program Aksi, Jakarta: 2014. Dapat diunduh melalui kpu.go.id/koleksigambar/VISI_MISI_Jokowi-JK.pdf

Kementerian Dalam Negeri Republik Indonesia, Daftar Perda/Perkada dan Peraturan Menteri Dalam Negeri Yang Dibatalkan/Revisi, 2016.

Komnas HAM, "Ringkasan Eksekutif Laporan Penyelidikan Pelanggaran HAM yang Berat Peristiwa Simpang KKA Aceh tertanggal 14 Juni 2016", diakses melalui https://www.-komnasham.go.id/index.php/hamberat/2016/09/29/2/ringkasan-eksekutif-laporanpenyelidikan-pelanggaran-ham-yang-berat-peristiwasimpang-kka-aceh.html, 5 November 2016.

Kompas,"Pemerintah Pilih Nyatakan Penyelesalan Ketimbang Minta Maaf Di Kasus HAM Berat", http://nasional.kompas.com/read/2016/01/05/20444951/Pemerintah.Pilih.Nyatakan.Penyesalan.Ketimbang.Minta.Maaf.di.Kasus.HAM.Berat, diakses 16 November 2016.

Liputan 6, "Usut Kasus HAM Berat, Pemerintah Bentuk Tim Gabungan", http://news.liputan6.com/read/2237035/usut-kasus-ham-berat-pemerintah-bentuk-tim-gabungan, diakses 5 November 2016.

Liputan 6, "Komnas HAM Janji Tindak Lanjuti Putusan Tragedi 65", http://news.liputan6-.com/read/2561214/komnas-ham-janji-tindak-lanjuti-putusantragedi-65, diakses 16 November 2016.

Priscilla Hayner, Fifteen Truth Commissions--1974 to 1994: A Comparative Study, Human Rights Quarterly, Vol. 16, No. 4, November, 1994.

Prolegnas Jangka Panjang Tahun 2010-2014

Prolegnas Jangka Panjang Tahun 2015-2019.

Prolegnas Prioritas Tahun 2011.

Prolegnas Prioritas Tahun 2015.

Prolegnas Prioritas Tahun 2017.

R. Herlambang Perdana Wirataman, Akses Keadilan Bagi Korban Pelanggaran Hak Asasi Manusia Berat Pasca Putusan Mahkamah Konstitusi Nomor 006/PUUIV/2006, Jurnal Rechtsvinding, Vol. 2 No. 2, Agustus, 2013.

\section{Dokumen Hukum}

Undang-Undang Dasar Negara Republik Indonesia Tahun 1945 Setelah Perubahan. Ketetapan Majelis Permusyawaratan Rakyat Nomor V/MPR/2000 tentang 
Pemantapan Persatuan Nasional. Undang-Undang Nomor 26 Tahun 2000 tentang Pengadilan HAM. Undang-Undang Nomor 21 Tahun 2001 tentang Otonomi Khusus Papua. Undang-Undang Nomor 11 Tahun 2006 tentang Pemerintah Aceh.

Undang-Undang Nomor 17 Tahun 2007 tentang Rencana Pembangunan Jangka Panjang Nasional.

Undang-Undang Nomor 12 Tahun 2011 tentang Pembentukan Peraturan Perundang-Undangan.

Keputusan Presiden Nomor 22 Tahun 2005 tentang Pemberian Amnesti Umum dan Abolisi Kepada Setiap Orang Yang Terlibat Dalam Gerakan Aceh Merdeka.

Qanun Pemerintah Aceh Nomor 17 Tahun 2013 tentang Komisi Kebenaran dan Rekonsiliasi Aceh.

Putusan Mahkamah Konstitusi Nomor 6/PUU-IV/2006 tentang Pengujian UU KKR. 